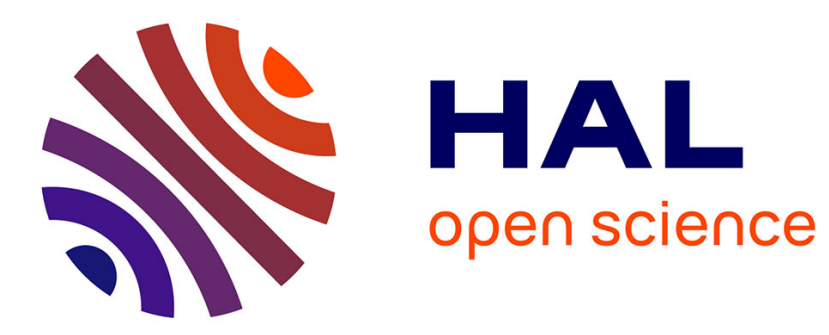

\title{
Comparison of three methods assessing the inundation caused by the erosion of an embankment
}

\author{
André Paquier
}

\section{To cite this version:}

André Paquier. Comparison of three methods assessing the inundation caused by the erosion of an embankment. La Houille Blanche - Revue internationale de l'eau, 2015, 4, pp.32-38. 10.1051/lhb/20150043 . hal-01254389

\section{HAL Id: hal-01254389 \\ https://hal.science/hal-01254389}

Submitted on 12 Jan 2016

HAL is a multi-disciplinary open access archive for the deposit and dissemination of scientific research documents, whether they are published or not. The documents may come from teaching and research institutions in France or abroad, or from public or private research centers.
L'archive ouverte pluridisciplinaire HAL, est destinée au dépôt et à la diffusion de documents scientifiques de niveau recherche, publiés ou non, émanant des établissements d'enseignement et de recherche français ou étrangers, des laboratoires publics ou privés. 


\title{
Comparison of three methods assessing the inundation caused by the erosion of an embankment
}

\author{
André PAQUIER
}

Irstea, UR HHLY, 69626 Villeurbanne, France, andre.paquier@irstea.fr

\begin{abstract}
Two test cases of embankment breaching are selected in order to compare a simplified model to 2-D calculations. The simplified model is based on an erosion model of the levee completed by the calculation of the head available between upstream and downstream sides of the embankment and two empirical models for wave propagation. The 2-D model is based on shallow water equations; it can be completed either by the same breach erosion model as in the simplified model or by an equation of sediment transport. The first test case is an experiment in Norway in which the embankment closes the valley. This latter example shows that all the models agree between them and differ from the experimental results because of the uncertainty of the input data and of the measurements. 2-D modelling does not bring any advantage except if sediment transport is simulated on a refined grid in order to obtain the detailed topography at any time. The second case is a breaching of a levee protecting the flood plain during high flows in Agly River. The difficulty stands in providing the hydraulic conditions in the river upstream from the breach and in propagating the flood wave in the complex topography of the flood plain. In such a case, the 2-D model that permits to test various assumptions and link them with physical processes can more easily provide an estimate of the uncertainty of the results
\end{abstract}

Key-words: breach, 2-D model, levee failure, sediment transport

\section{Comparaison de trois méthodes estimant l'inondation causée par l'érosion d'un remblai}

RÉSUMÉ. - Deux cas tests de rupture de remblai ont été sélectionnés afin de comparer un modèle simplifié d’inondation à des calculs bidimensionnels. Le modèle simplifié est construit, d'une part, à partir d'un modèle d'érosion d'une digue complété par le calcul de la charge disponible entre l'amont et l'aval du remblai afin de calculer le débit transitant par la brèche et, d'autre part, à partir de deux modèles empiriques de propagation d'onde, l'un traitant le cas d'un écoulement selon un axe hydraulique marqué alors que l'autre traite un écoulement sur une topographie plane. Le modèle bidimensionnel est basé sur la résolution des équations de Saint Venant ; il peut être complété soit par le même modèle d'érosion de remblai que dans le modèle simplifié ou par une équation de transport de sédiments. Le premier cas test est une expérience en Norvège dans laquelle le remblai ferme la vallée. Ce premier exemple montre que tous les modèles numériques donnent des résultats similaires mais différents des observations à cause de l'incertitude à la fois sur les données d'entrée et sur les mesures. Le modèle bidimensionnel n’apporte aucun avantage sauf si le transport de sédiments est simulé sur un maillage fin afin d'obtenir une chronologie complète de la topographie détaillée, en particulier, au droit de la brèche. Le second cas test est la rupture d'une digue protégeant le lit majeur de l'Agly pendant une forte crue de la rivière associée à un niveau marin élevé (événement de novembre 1999). La principale difficulté réside dans la fourniture des conditions hydrauliques au droit de la brèche du fait des incertitudes sur l'hydrogramme amont et des débordements en amont de la brèche ; la propagation de l'onde de crue sur la topographie complexe du lit majeur est aussi difficile à cause de la présence de nombreux bâtiments et ouvrages (remblais et franchissements de ces remblais) et des érosions et dépôts. Dans un tel cas, le modèle bidimensionnel qui permet de tester des hypothèses variées en les liant aux processus physiques peut plus facilement fournir une estimation de l’intervalle d'incertitude des différents résultats.

Mots-clefs : brèche, modèle bidimensionnel, rupture de barrage, transport de sédiments

\section{INTRODUCTION}

A lot of floodplains along rivers are protected by earthen embankments. During extreme floods, these embankments can be overflowed. Runoff over the downstream side of the embankment can create erosion and, beyond, can lead to the failure of the embankment. According to the rapidity of the processes, flooding downstream the embankment can be more or less violent, extreme cases leading to very high velocities that can destroy buildings and thus generating consequences much higher than common floods.
The main parameters used for the risk analysis are the flow velocity and the water depth during the flood. To obtain these hazard values, hydrodynamic calculations can be used. Restricting the presentation to the case of a flood located along a river for which part of the floodplain is protected by levees, three processes should be modelled:

- flow inside the main channel including the part of the flood plain that is not protected by levee;

- breaching of the levee;

- flooding of the protected area.

These three processes are coupled because, in one hand, the opening of a breach will modify the flow inside the main 
channel and, in the other hand, the flow conditions upstream and downstream from the levee are (together with the levee characteristics) the main parameters of the evolution of the breach shape and of the flow through the breach. A calculation without coupling the processes will overestimate the water level upstream the breach and increase the rate of erosion of the breach.

Upstream from the breach, the derivation of part of the flow to the breach (while the main flow still follows the river main channel) leads to select two-dimensional shallow water equations to predict water elevation accurately. Similarly, downstream from the breach, two-dimensional shallow water equations should be preferred because the flow propagation has no favoured direction if the breach is not linked to an existing channel in the flood plain. The use of a 2-D model can be improved taking into account the transport, the erosion and the deposition of the embankment sediments, processes that can modify the risk assessment, at least, because of the local rise of water elevation. Such a model can also integrate the soil erosion caused by the high velocities downstream the breach. However, for a risk management plan, a detailed analysis is not always necessary. For instance, only the boundaries of the areas at high level of risk should be drawn; thus a simple approach can be tried.

For the erosion during breaching, Irstea developed simplified software called Rupro [Paquier, 2007] in order to get a flow hydrograph through the embankment and calibrated it to cope with experiments. This software was integrated in other software developed by Irstea that solve either 1-D or 2-D shallow water equations and are convenient for simulating rapid flows [Paquier, 1998]. Rupro was also integrated in CastorDigue software [Renzoni et al., 2005] in which the downstream flow is assessed using analytical and empirical equations.

After the description of the three methods that will be tested (CastorDigue, 2-D shallow water equations and 2-D with sediment transport), a comparison of calculation results is performed for two examples. The first one deals with an embankment closing a valley; it shows the ability to obtain a flow hydrograph. The second one illustrates the propagation of the flow and of the sediment in the flood plain downstream a breach in a levee.

\section{DESCRIPTION OF THE NUMERICAL MODELS}

\section{II.1. Presentation of CastorDigue Software}

Irstea (formerly Cemagref) developed specific software named CastorDigue (Simplified calculation for the treatment of the wave created by the breaching of a dike). The problem is simplified distinguishing four areas [Paquier et al., 2005]: - the river main channel described by a series of cross sections;

- the breach area described by a trapezoidal cross section for the levee and a rectangular cross section for the breach itself (except at the beginning of piping in which the breach section is circular);

- the near-field area in which a two-dimensional propagation occurs on an inclined plane;

- the far-field area in which the propagation turns to be one-dimensional.

In every area, a simplified model is used. At the cross section of the river in which the breach occurred, the water level is determined by a rating curve from the flow discharge in the river; this part can be replaced by directly providing the water level along the time or by calculating the water level of a reservoir (to be described by a curve providing stored volume at any elevation). The breach model is based on Rupro model described here below. In the near-field area, an empirical relation from [Whitham, 1955] is used to calculate the front propagation and the water depth near the front while the lines of equal water depth and the lines of equal water velocity are ellipsoids centred on the breach location, the equal values being estimated from an approach similar to Ritter solution [Paquier, Beraud, 2010]. Finally, in the far-field area, the peak discharge is obtained through a reduction coefficient calculated from the slope, the friction coefficient and a non-dimensional distance calculated from the volume passing by the breach; then, a relation similar to the uniform flow equation is used to determine peak water depth, peak velocity and time to arrival (method developed for Castor software [Paquier, Robin, 1997]).

Rupro model is based on the main hypothesis that the flow processes are not modified by the high concentrations of sediment, even during the beginning of the erosion process. The embankment is supposed to be of trapezoidal shape and of homogeneous material. Water flows through a pipe or a channel that is modelled by one mean cross section and zero slope [Paquier, 2007]. The evolution of the breach includes three steps. Step 1 is the initial state: flow is nearly zero and erosion can be neglected. During the second step, water starts flowing through a circular pipe (piping) or a rectangular breach (overtopping) and erodes the circumference or the bottom of the breach so that its diameter or its depth is increasing with time. In a third step, either after the diameter of the pipe has reached $2 / 3$ of the dam height and the vault of the pipe had consequently failed or after the bottom of the dam is reached, water flows in a rectangular channel the width of which is increasing due to erosion of its walls. Although, these shapes and evolutions are very simple, they correspond to a relevant first-order estimate; particularly, during overtopping, the walls of the breach are nearly vertical, which explains that taking into account a trapezoidal breach could hardly improve the results. To compute average flow variables within the pipe or the channel, Bernoulli equation is used between upstream and downstream water elevations, the linear head loss being computed using Manning equation. The sediment discharge from which the erosion rate is deduced is computed using the hydraulic variables in the breach cross section and the equation from [Meyer-Peter, Müller, 1948].

\section{II.2. Presentation of Rubar 20 software}

The code Rubar 20 solves 2-D shallow water equations by an explicit finite volume scheme. The second order Godunov-type scheme includes 2 main steps which consists in, first, estimating the fluxes through edges for the conservative part of the equations, and then, integrating second member of the equations on the surface of the cell in order to add the corresponding contribution. Except for the case of a hydraulic structure, the estimate of the flux through one edge is computed solving (approximately e.g. Roe type linearization) a 1-D Riemann problem perpendicularly to the edge. Thus, the computation of discontinuities or fronts is included in the scheme as ordinary points, so that there is no need of any particular treatment for drying and wetting [Mignot et al., 2006]. The mesh consists of quadrilaterals or triangles having 0 or 1 (full) common edge. The mixing 
of these two kinds of cells provides various possibilities to adapt to any detail of topography.

A hydraulic structure is defined as a set of a few cells in which fluxes through one edge are computed using the equations for the hydraulic structure linking discharge and water levels upstream and downstream (for instance, weir equation). Defining a specific hydraulic structure constituted by the Rupro model permits to couple the breach model with the 2-D shallow water equations simply prescribing the upstream and downstream water levels from this latter hydrodynamic calculation.

When the flood lasts several days, the breaching process is relatively rapid and the breach can be modelled using a weir equation of predetermined evolving parameters or even more simply using an instantaneous opening in the embankment because the essential point is the final shape of the breach that will determine the inflow in the flood plain. However, in the near field, immediately after the start of breaching, the use of an instantaneous breaching will overestimate the velocities and thus the risk.

\section{II.3. Presentation of Rubar 20TS software}

The 2-D shallow water equations are completed by a sediment transport equation (1):

$$
\frac{\partial(C h)}{\partial t}+\frac{\partial\left(C h u_{s}\right)}{\partial x}+\frac{\partial\left(C h v_{s}\right)}{\partial y}=\frac{\partial}{\partial x}\left(h K \frac{\partial C}{\partial x}\right)+\frac{\partial}{\partial y}\left(h K \frac{\partial C}{\partial y}\right)+E
$$

in which $E$ is the rate $(\mathrm{m} / \mathrm{s})$ of bed elevation evolution (erosion if positive or deposition if negative), $C$ the concentration of suspended particles $\left(\mathrm{m}^{3} / \mathrm{m}^{3}\right), u_{s}$ and $v_{s}$ the sediment velocities $(\mathrm{m} / \mathrm{s})$ in the $x$ and $y$ directions (generally - and in the two presented test cases - set equal to water velocities), $h$ the water depth (m), $K$ a diffusion coefficient $\left(\mathrm{m}^{2} / \mathrm{s}\right)$ (equal to the water diffusion coefficient in the two presented test cases). $E$ is either calculated from an empirical equation providing the maximum sediment transport capacity (case of bed load) or more simply set proportional to the deviation to a critical shear stress (used in the two presented test cases with a coefficient of $0.0001 \mathrm{~m} / \mathrm{s}$ ) or to an equilibrium concentration (case of suspended load) [Paquier, 2013]. $E$ is calculated at each node and is then averaged in the cell in order to obtain sediment input or output to fill equation (1). Bed elevation evolves considering $E$ at every time step. This equation (1) is solved using a first order finite volume scheme and using the same time step as shallow water equations with which it is coupled through exchanges of water depth, velocity and bed elevation.

\section{DESCRIPTION OF THE TEST CASES}

\section{III.1. Dam failure experiment}

A series of experiment in Norway concerned the erosion of 5 to 6 meters high embankments built across a river. The measurements were performed during the European project Impact, which permitted to get reference data [Morris et al., 2007]. In the test 1 retained in this paper, the embankment was homogeneous made of clay and silt with median diameter about $0.01 \mathrm{~mm}$. The upstream water level is first raised and maintained a little below the embankment crest in order to initiate the erosion process along a $5 \mathrm{~m}$ wide opening of which the bottom is a few centimetres below the crest elevation. Then, the upstream discharge (provided by the gates of a larger dam a few kilometres upstream) is stopped to model the effect of a limited water volume (case of a reservoir). The main variables to obtain are the flow discharge through the breach and the breach deepening and widening. For calculations, the upstream discharge hydrograph is introduced in the river at the upstream end (about $600 \mathrm{~m}$ from the dam) for 2-D models and in the reservoir upstream the embankment for CastorDigue. The 2-D calculation mesh (4320 cells) is built to set a space step of about $1 \mathrm{~m}$ at the breach location (Fig. 1). If the breach is represented by specific hydraulic structures, the breach is split into 21 structures, each one being located between one edge at the upstream toe of the embankment and one edge at the downstream toe of the embankment (between these two edges located on Fig. 1, no calculation using shallow water equations is performed but the Rupro model is used to provide breach variables and particularly the flow discharge to be transferred); when, inside one structure, the breach is fully developed (it reached both lower bottom elevation and full width), the erosion inside the following structure starts (the order of opening is defined by the user, generally from the centre of the breach to the extremities). The Manning coefficients are set to $0.04 \mathrm{~s} / \mathrm{m}^{1 / 3}$ and the diffusion coefficient to $0.1 \mathrm{~m}^{2} / \mathrm{s}$.

\section{III.2. Agly levee failure}

The overflow of Agly levee East from Rivesaltes during the November 1999 flood [Paquier et al., 2002] leads to the flooding of a wide coastal plain, quite horizontal in which flow is limited by several road embankments. The high flood that occurred in the southern part of France near the Spanish Border in November 1999 was one of the highest of the 20th century in the lower reach of Agly River. On November 12 and 13, 1999, the river basin received rainfalls between 200 and $400 \mathrm{~mm}$ within about one day. The peak discharge

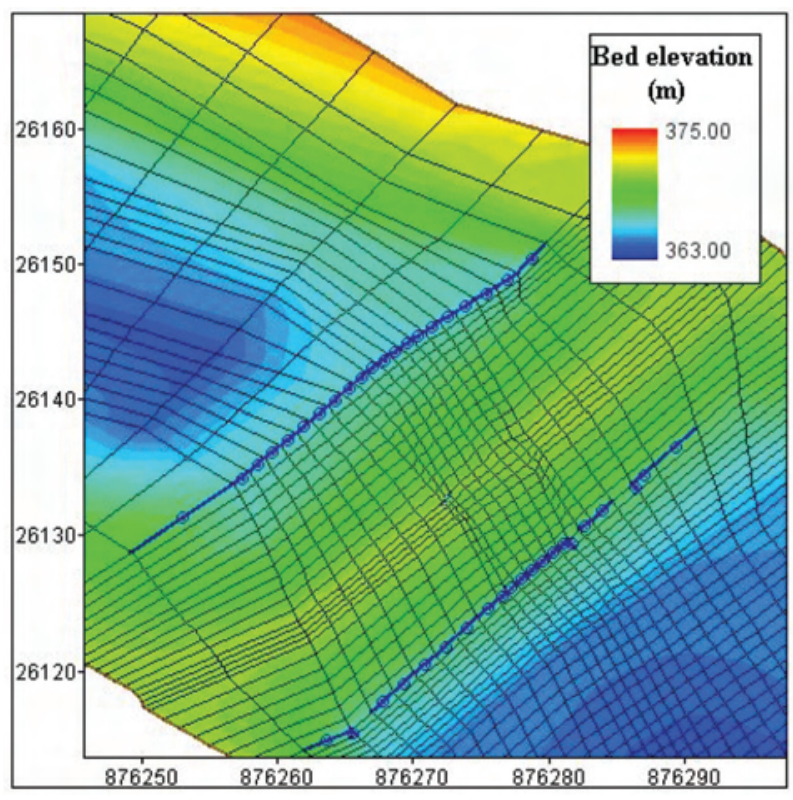

Figure 1: Zoom of the central part of the calculation mesh for the Impact case. The upstream and downstream edges of the structures are located by blue lines and circles. The distances along $x$-axis and $y$-axis are in metres. 
reached about $2000 \mathrm{~m}^{3} / \mathrm{s}$ (return period of about 100 years), which was higher than the conveyance of the main channel between the dikes in the lower reach (about $1500 \mathrm{~m}^{3} / \mathrm{s}$ ). Several overflows occurred along the dikes. These overflows were the cause of the flooding of large areas but only with a few centimetres of water. However, one of these overflows was the origin of a breach (about $40 \mathrm{~m}$ wide and $3 \mathrm{~m}$ high on average) at the start of the falling phase of the discharge hydrograph. This latter breach suddenly released a two metre high wave that destroyed a sewage plant in Saint Laurent de la Salanque and flooded the village. The flooded area is limited by the embankments around the village because the flow can only go downstream through the hydraulic structures crossing these latter levees.

A 2-D model of the whole flood plain (18568 cells) is built in order to simulate the 1999 flood (Fig. 2). The space step varies from about 5 metres on the embankments to 200 metres in the plain. Although there was heavy rain over the area, a first simplification is to introduce only one discharge hydrograph at the upstream end of the Agly main channel. Selected Manning coefficients vary from $0.0125 \mathrm{~s} / \mathrm{m}^{1 / 3}$ in the river at the crossing of the town of Rivesaltes to $0.14 \mathrm{~s} / \mathrm{m}^{1 / 3}$ in the villages. Generally, the Manning values in the flood plain do not influence the results too much because of the influence of the embankments and ditches that cross the flood plain. Manning value in the main channel is calibrated in order to obtain observed peak water elevation between the levees. However, at the peak of the 1999 flood, the water elevation is close to the top of the levees and only a discharge of about $1500 \mathrm{~m}^{3} / \mathrm{s}$ should be considered. Thus, for the simplified model CastorDigue, the discharge hydrograph is limited to $1500 \mathrm{~m}^{3} / \mathrm{s}$ and a delay of two hours is introduced in order to take into account the propagation time between the upstream end of the 2-D model and the breach location. Using the same Manning coefficient as the 2-D model for the river section in which the breach is located, the slope is adjusted to $0.05 \%$ (which is close to the mean slope of the flood plain) in order to obtain an equivalent peak water elevation of about $6.6 \mathrm{~m}$ A.S.L. In the 2-D model, the breach is located on three edges in order to define a trapezoidal shape in case of instantaneous failure and three structures in case of progressive erosion. The sediment diameter is set to $1 \mathrm{~mm}$ for both the levee and the floodplain soil layer considering that both are alluvial deposits from Agly River.

\section{COMPARISON OF RESULTS}

\section{IV.1. Dam failure experiment}

Fig. 3 compares the flow discharges obtained by the simplified model and the 2-D model with the flow discharge estimated after the experiments using field measurements. Obviously, the behaviour of the field estimate differs from

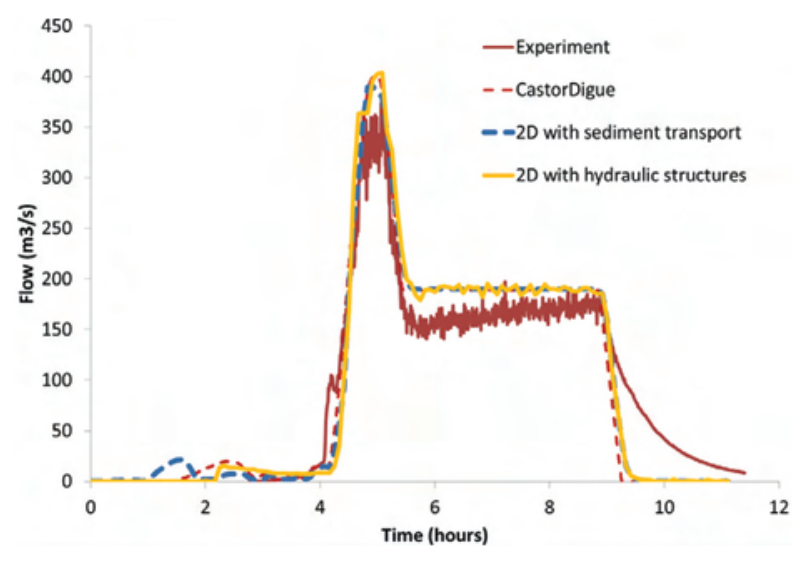

Figure 3: Flow hydrographs at breach site for Impact case.

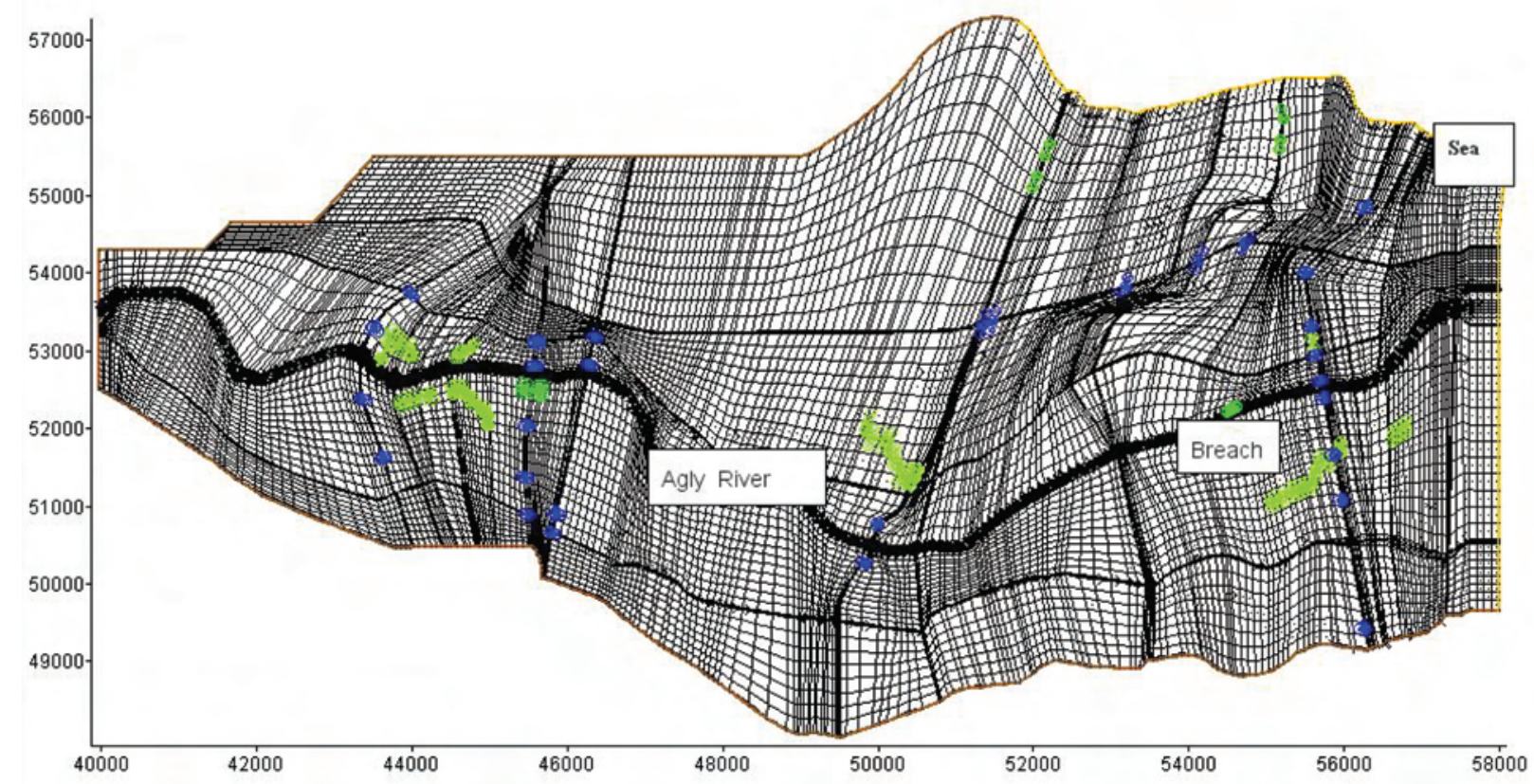

Figure 2: 2-D calculation mesh of Agly test case. The hydraulic structures are marked using coloured cells (blue for openings crossing levees, green for walls). The distances along $x$-axis and $y$-axis are in metres. 
other results: the low discharge between 1 to 4 hours was not observed; the decrease of upstream discharge down to $190 \mathrm{~m} 3 / \mathrm{s}$ after the peak provides a decrease of breach discharge below this value which means a storage of water upstream the dam, volume that will be evacuated downstream after 9 hours (stop of upstream discharge). A first cause of the discrepancies at the beginning of the experiment consists in some flow discharge passing beside the breach while, in the calculations, it passes by the breach and creates some erosion. Because of this earlier development of the breach in the calculations, the breach is then wider and the flow discharge higher than in the experiment. The calculated breach flow discharge is close to the input flow discharge at the upstream end of the reservoir and this immediate answer to a change also reveals that the storage in the reservoir due to the backwater curve is not conveniently taken into account. Because these discrepancies are present in any numerical model, the three calculation results agree between them; only the first flows are different. Moreover, the 2-D model with hydraulic structures shows slight instabilities after the peak when the flow is nearly steady; one cause is the insufficient coupling between the calculation of the wave propagation (second order scheme) and the calculation of the flow discharge through hydraulic structures that is only calculated at the start of the time step.

The breach width evolution can be also compared. In the experiment, the breach is enlarging to the final width of 23 metres essentially during one hour (between 4 and 5 hours). CastorDigue widens the breach slowly up to 9 metres during the four first hours, then to 23 metres at the peak flow and then more slowly up to 31 metres at the time (about 9 hours) in which the flow is suddenly decreasing. For the two 2-D models (breach as structure or sediment transport), the breach either goes to the full width of the valley (particularly with the selected reference parameters for which the flow hydrographs are presented in Fig. 3). But with some alternative sets of parameters, there is nearly no erosion, which means an issue still exists about the choice of the suitable values of the sediment parameters. The advantage of the 2-D model with sediment transport is the possibility to provide the full topography of the embankment at any time. For instance, Fig. 4 shows the cross section of the valley just downstream the crest. Moreover, deposition of the eroded materials can be simulated if sediment transport

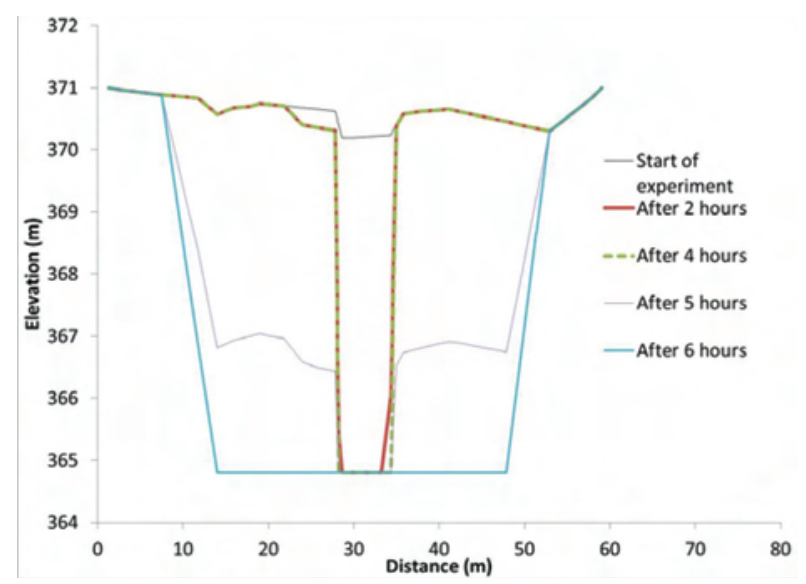

Figure 4: Evolution of a valley cross section close to breach crest. The 2-D model with sediment transport for Impact case used as basis for the picture has only 27 points across the valley. is calculated; however, in this test case, all the sediments are washed away very rapidly except in the early stages of breaching in which the velocities remain quite low downstream. In case of 2-D model with hydraulic structures representing the breach, the relevant discretization of the breach to minimize instabilities and to reproduce the shape of the breach at various times is still to be found.

\section{IV.2. Agly levee failure}

In this test case, more complex than the first one, information from field observations are used to define the water elevation upstream from the breach in CastorDigue calculation and the approximate width of the breach used to set the discretization around the breach for the 2-D calculation. From these observations, the elevation of the bottom of the breach can be fixed either to $2.4 \mathrm{~m}$ A.S.L. (lower observed elevation of the breach bottom after breaching) or to $3.4 \mathrm{~m}$ A.S.L. (elevation at the downstream toe of the embankment before breaching). The reference calculation uses this latter value that does not involve erosion of the flood plain soil. Using this hypothesis, CastorDigue provides a final width of the breach of about 19 metres which is half the final width but corresponds to the width of the deeper part of the breach (without taking into account the banks that have rather mild slopes). For the 2-D models, it is also the case most of the time because the mesh is very coarse and the flow discharge on the two sides cells are null or very limited while the central cell is about $19 \mathrm{~m}$ wide. However, while, the final width is a calculation result for CastorDigue, smaller cells would be necessary around the breach (similarly to the first test case) in order to get an assessment of the breach development.

Instantaneous breaching provides a higher peak discharge than progressive breaching (Fig. 5) with similar peak for CastorDigue and Rubar 20 using the same Rupro model. If the bottom of the breach is lower, the peak flow can nearly double, which means that the uncertainty should remain very high if one cannot provide an accurate estimate of this bottom elevation. However, figures 6 and 7 (for the minimum breach bottom elevation set to $3.4 \mathrm{~m}$ A.S.L.) show that the propagation modelling is also producing a quite high uncertainty if a simplified method is used.

The embankments within the floodplain invalidate the hypotheses used to build CastorDigue in the area downstream

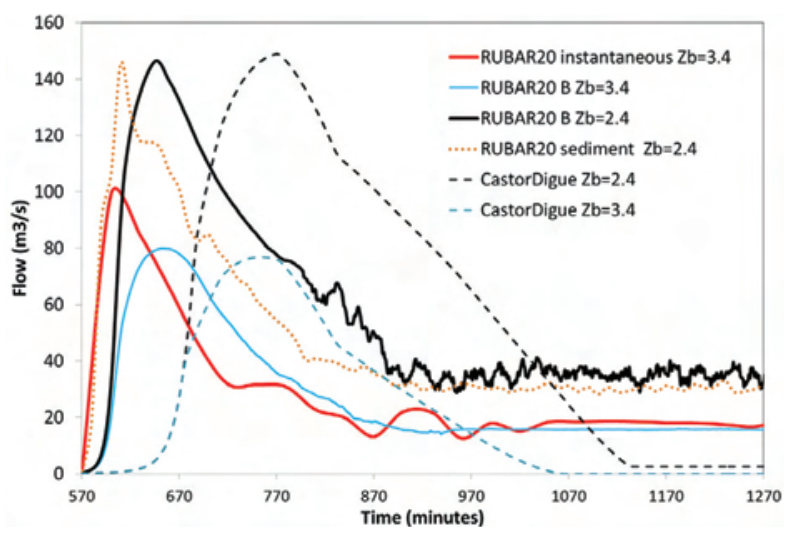

Figure 5: Flow discharge at the breach site for Agly case. 


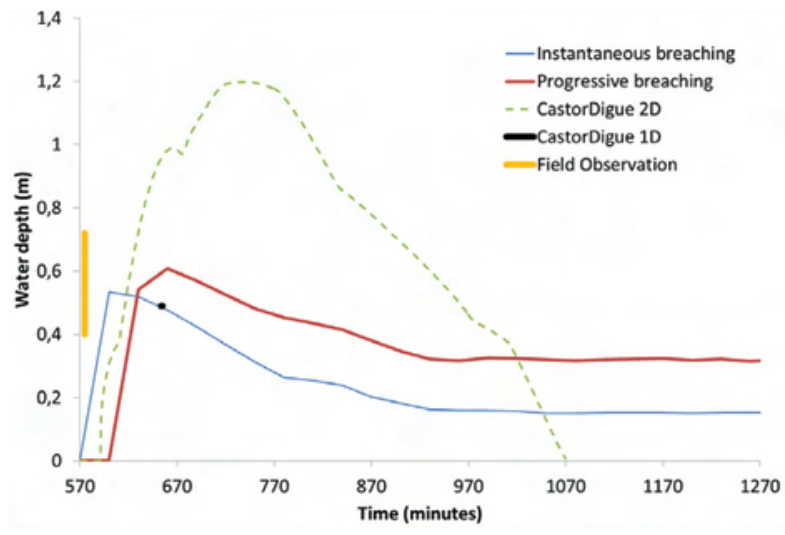

Figure 6: Water depth evolution at 300 metres from the breach for Agly case. Breach bottom deepening is limited to 3.4 m A.S.L. 1-D propagation in CastorDigue only provides the peak water depth and the time for the peak hence only one point on the picture. Field observation is limited to an approximate peak water depth without time hence a vertical segment (to get an estimate of the range of uncertainty) arbitrarily put along the vertical axis.

the breach, which implied either a free propagation in all the directions or the concentration of the flow in one direction. Thus, using such latter software, uncertainty is quite high for downstream water depth (or velocity). The 1-D model of far field of CastorDigue using a triangular cross section with a width of 1500 metres at a water depth of 1 metre and a slope of $0.1 \%$ provides a peak water depth similar to Rubar 20 but a different peak velocity. The slower rise of the breach discharge for CastorDigue partly explains the lower velocity and higher water depth for the CastorDigue 2-D simplified model used with the same Manning coefficient of $0.067 \mathrm{~s} / \mathrm{m}^{1 / 3}$ (as the other models) and a slope of $0.13 \%$. Because it takes into account the propagation processes along the time, 2-D full modelling reduces the uncertainty concerning the propagation and permits to introduce secondary processes such as the wind effect, the soil infiltration or the presence of buildings or levees in the flood plain.

Adding sediment transport inside the floodplain to 2-D full modelling does not permit to reduce the uncertainty because the results are very sensitive to the parameters of the sediment transport model. The calculations performed with reference parameters and the breach simulated by Rupro model lead to deposition of the sediment from the breach immediately downstream (within a distance of less than $200 \mathrm{~m}$ ) because of a rapid reduction of velocities (down to less than $0.5 \mathrm{~m} / \mathrm{s}$ as shown on Fig. 7). A calculation assuming that both the embankment at the breach location and the soil downstream the breach have a high erosion rate can provide a location of eventual areas of erosion and deposition (Fig. 8). The breach is eroded down to $2.4 \mathrm{~m}$ A.S.L. and erosion goes even deeper downstream close to the breach. All the sediments eroded as far as 600 metres from the breach are rapidly deposited because the area is surrounded by road embankments that retained the flow because of the limited flow conveyance of the hydraulic structures that cross these embankments. Note that the Eastern erosion is due to overflow over the Agly left bank levee immediately upstream a bridge over Agly River. If the sediment transport is taken into account for both the embankment and the downstream

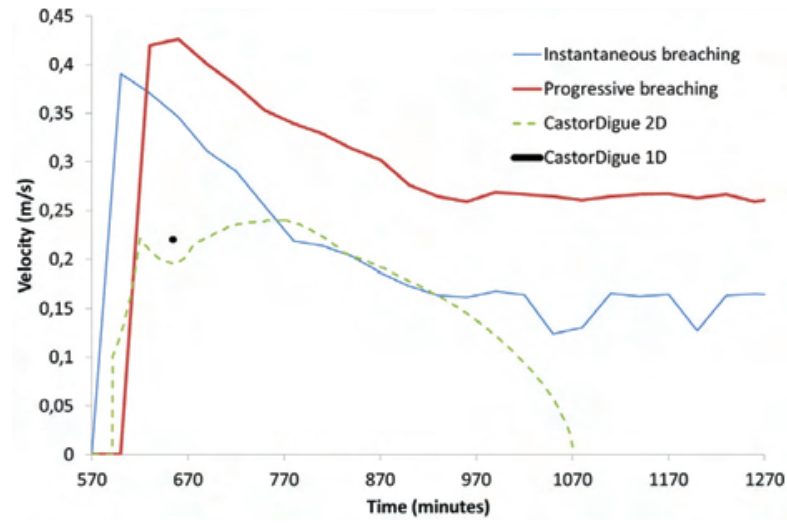

Figure 7: Velocity evolution at 300 metres from the breach for Agly case. Breach bottom deepening is limited to $3.4 \mathrm{~m}$ A.S.L. 1-D propagation in CastorDigue only provides the peak velocity and the time for the peak hence only one point on the picture.

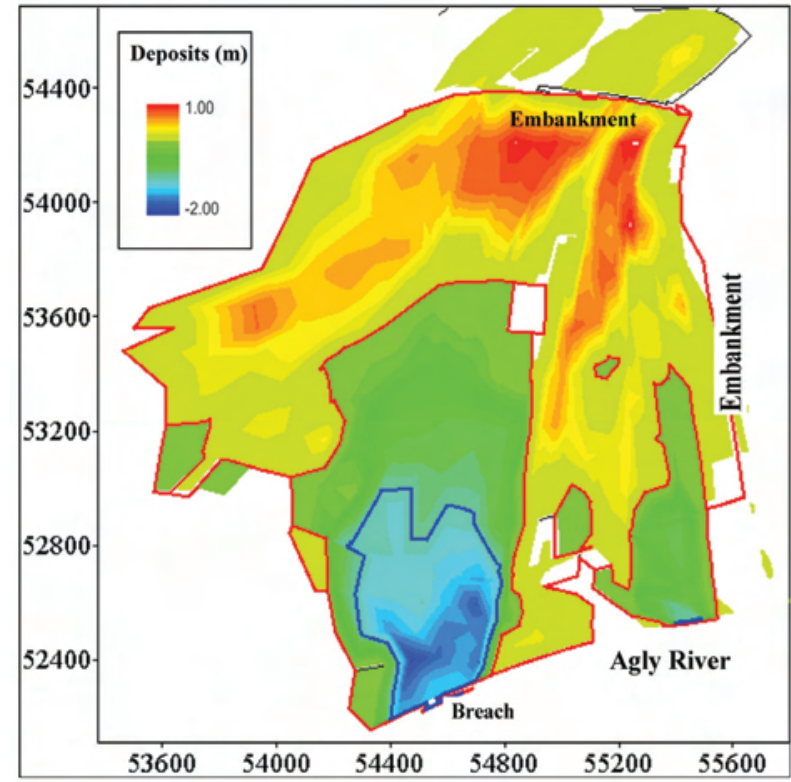

Figure 8: Evolution of topography because of breaching for Agly case. Breach bottom deepening is limited to $2.4 \mathrm{~m}$ A.S.L. The red line marks the limit of the deposition or erosion areas; the blue line marks the limit of erosion deeper than 1 metre. The distances along $x$-axis and $y$-axis are in metres.

area, the discharge hydrograph (Fig. 5) shows first the effect of a quick erosion of the embankment and then a reduction of the flow caused by the backwater influence due to the deposits. In the downstream area, the consequences for water depth and velocity vary between the deposition and erosion areas. Generally, the coarse mesh used in this study leads to a high sensitivity of the results to the sediment parameters; however, such a set of calculations can provide an assessment of the range of uncertainty and thus, it is useful for flood mitigation measures. 


\section{CONCLUSIONS}

For both cases, either a simple erosion model (Rupro) or a classical sediment transport model can provide realistic discharge hydrographs at breach site using usual values for equation parameters. The first test case in which the embankment closes the valley shows that all the models provide similar results that slightly differ from the experimental results because field circumstances are not accurately modelled and perhaps because some uncertainty also exists for the measurements. The flow propagation being essentially 1-D, 2-D modelling does not bring any clear advantage except if sediment transport is simulated on a refined grid in order to obtain the detailed topography of the embankment at any time. The second case is more representative of a breaching of a levee protecting a flood plain. The difficulty stands in providing the upstream boundary conditions and in propagating the flood wave in the complex topography of the flood plain. In such a case, the 2-D model that permits to test various assumptions and link them with physical processes can more easily provide an assessment of the uncertainty range for any result. However, without a refined mesh of the breach and of the downstream area, the sediment transport modelling cannot reduce the uncertainty linked to the estimate of the bottom elevation and the breach widening.

\section{ACKNOWLEDGEMENTS}

We thank the European Union that funded the Impact project and all the partners of the project, particularly HR Wallingford and Sweco that led the experiments in Norway.

\section{REFERENCES}

Meyer-Peter E., Müller R. (1948) - Formulas for bed-load transport. Report on second meeting of IAHR. IAHR, Stockholm, Sweden. 39-64
Mignot E., Paquier A. And Haider S. (2006) - Modeling floods in a dense urban area using 2D shallow water equations. Journal of Hydrology. 327 : 186-199

Morris M. W., HASSAN M.A.A.M., VASKInN K.A. (2007) - Breach formation: Field test and laboratory experiments. Journal of Hydraulic Research. 45 (sup1) : 9-17

PAQUIER A. (1998) - 1-D and 2-D models for simulating dam-break waves and natural floods. M. Morris, J.-C. Galland and P. Balabanis (Ed.) Concerted action on dam-break modelling, proceedings of the CADAM meeting, Wallingford, United Kingdom. European Commission, Science Research Development, Hydrological and hydrogeological risks., L2985, Luxembourg. 127-140

PAQuier A. (2007) - Testing a simplified breach model on Impact project test cases. In: G.D. Silvio and S. Lanzoni (Ed.). Proceedings of XXXII IAHR Congress. IAHR, Venice, Italy

PAQuier A. (2013) - Logiciel Rubar 20. Notice d'emploi. Irstea, Villeurbanne, France

PAquier A., Robin O. (1997) - CASTOR, a simplified dam-break wave model. Journal of Hydraulic Engineering ASCE. 123(8) : 724-728

Paquier A., Fang Z.X., Rouch B. (2002) - Hydraulic modelling of the 1999 flood in the lower reach of Agly river. In: Y. Zech (Ed.). Proceedings of River Flow 2002. Université Catholique de Louvain La Neuve, Louvain, Belgium. 247-252

Paquier A., Renzoni J., Cogoluegnes A. (2005) - Quick estimate of flood risk downstream of a dike breaching. In: J.V. Alphen, E.v. Beek and M. Taal (Ed.). Floods from Defence to Management, 3rd International Symposium on Flood Defence, Nijmegen, Rotterdam: Balkema, The Netherlands. 371-376

Paquier A., Beraud C. (2010) — Validating a simplified model for flood hazard downstream levees. In: A. Dittrich, K. Koll, J. Aberle and H. Geisenhainer (Ed.). Proceedings of River Flow 2010 Conference, Braunschweig, Germany. 591-597

Renzoni J., Paquier A., Cogoluegnes A. (2005) — Un outil d'estimation rapide du risque d'inondation à l'aval d'une digue. Méthodes et premières étapes de validation. Ingénieries - E A T (Spécial Sécurité des digues fluviales et de navigation). 47-53

Whitham G.B. (1955) - The effects of hydraulic resistance in the dam-break problem. Proceedings of the Royal Society of London, Series A. (227) : 399-407 